\title{
Location Theory, Regional Growth Theory And Manufacturing In The Antebellum South and Midwest\#
}

\author{
Raymond L. Cohn*
}

\section{INTRODUCTION}

The location of industries is a subject which is treated both by location theory and by regional growth theory. Location theory attempts to explain how firms in a particular industry choose a production site. The exportbase theory of regional growth, on the other hand, is concerned with identifying those industries which produce products mainly for consumers external to the region. This "export base" set of industries is thought to determine the growth possibilities of the region, and is thus of interest to regional growth economists. The two approaches have sometimes been joined at places where the connection does not always hold. This paper investigates one assumed connection between the theories, that between industries which locate near their resources and industries which export their output. ${ }^{1}$ It is shown that this connection does not always hold by providing a general analysis of location for each theory. Further, the importance of this connection for United States antebellum manufacturing is discussed.

\section{ANALYSIS}

This paper adopts a terminology set which allows a distinction to be made between location according to the principles of location theory and location according to the principles of regional growth theory. First, consider location theory. The subject of location theory is to explain why a firm chooses one specific site over another specific site within a region. The terms "resource-oriented," "market-oriented," and "footloose" will refer to this locational decision. Thus, a "resource-oriented" industry is one whose firms are "pulled" to a production site near their resources, while a "market-oriented" industry is one whose firms are "pulled" to a production site near their market. A "footloose" industry is one whose firms are "pulled" neither to a site near their resources nor their markets. The "pulling" mechanism is, or course, the desire to minimize total costs, i.e., the costs of production plus transportation costs.

*Assistant Professor of Economics at Illinois State University.

\#The author wishes to thank James N. Tattersall for reading and commenting on earlier drafts of this paper. 
The situation is somewhat different when we look at regional growth theory. Industries are generally classified according to whether they produce primarily for the regional market or whether they produce primarily for export. The specific location site within the region is not important, only whether the firms locate in the region on the basis of external or internal consumer demand for their products. The terms "exportoriented" and "consumer-oriented" will refer to this regional location decision. Thus, an "export-oriented" industry is one whose firms locate in a region and primarily satisfy demand external to the region, whereas firms in a "consumer-oriented" industry locate in a region and sell their output primarily within the region.

While "resource-oriented," "market-oriented," and "footloose" are mutually exclusive categories as are "export-oriented" and "consumeroriented," obviously the first three are not mutually exclusive of the latter two categories. In particular, the assumption is often made that "resource-oriented" industries are a subset of "export-oriented" industries. This relationship need not always hold, though it may at certain times and in certain places. One purpose of this paper is to clarify the relationships between all five industry types given above. To accomplish this clarification, let us specify seven different types of industries which we can identify and classify according to the above categories.

The first industry is an industry whose firms locate near a nonubiquitous resource. This industry is a standard example of a "resourceoriented" industry. We can now denote two other types of industries; one exists on either side of the resource-oriented industry's production process. Our second group consists of industries involved in the secondary processing of resources which locate near a resource-oriented industry and use that industry's output as its own input. An example of this type would be the automobile industry which located near its principal resource, flat sheet steel, for many years. The third group are those industries which supply needed equipment to the resource-oriented industry and which also locate near it. Examples here would be industries which produce special machinery and special clothing for a resource-oriented industry.

These first three groups should all be considered as export-oriented even though not all produce directly for export. The location and amount of these industries in a region depends either directly or indirectly on the availability and types of resources contained by the region and on the external demand for the products produced using these resources. Two examples should clarify the situation. Notice that a standard resourceoriented industry does not necessarily have to export its output. It may sell this output to a secondary processor who then could be the one that exports. Eventually, though, the product of the first-group industry will be exported in one form or another. For the second example, consider an industry in our third group. These industries certainly don't export their products; by definition, they are locating near their output market. However, the demand they are supplying is not consumer demand within the region but demand from other industries which eventually export their 
own output. In the final analysis, the amount of this third group of manufacturing located in a region depends upon demand from outside the region and upon the extent and type of resources available in the region. Thus, it is properly classified as being export-oriented.

The next three industry types are all consumer-oriented. The fourth group is the standard market-oriented industry. This type of industry locates in a region to sell its product to consumers residing there. By definition, it is serving final demand within the region where it is located and is therefore consumer-oriented. The fifth group consists of those industries which supply a market-oriented industry with needed materials and which locate near this market-oriented industry. An example would be an industry which produces cardboard milk containers. The key idea is that an industry should be considered consumer-oriented if its firms locate in a region because of the presence in the region of consumer demand for their product. It does not matter whether this presence exerts itself directly or indirectly. The fifth group obviously satisfies this criterion and thus should be considered consumer-oriented.

Our sixth group consists of those resource-oriented industries which locate at an ubiquitous resource site. These industries are properly classified as consumer-oriented. ${ }^{2}$ If a particular resource is ubiquitous, the firms in the industry have the option of locating in any region. The firms will locate at resource sites within whatever region is chosen, but won't choose one region over another on the basis of the presence or absence of the needed resource. These firms will choose one region over another because of the existence of a greater consumer demand for their products in the chosen region. Thus, firms in this type of industry will not export their products, and the industry should be classified as being consumeroriented.

An example should clarify the types of industries comprising our sixth group. Consider the lumber industry. Cohn [3] has shown that sawmills locate as close as possible to the standing timber. Thus, a study of the production site chosen by a sawmill in a particular region will show that the sawmill is resource-oriented. However, if, in the country under study, lumber is a basically ubiquitous resource (as it was in the settled area of the United States in 1860), a quite different result will be obtained if we ask the reasons for choosing one region over another. Sawmills will choose one region over another on the basis of consumer demand for lumber products within each region. If we attempted to explain the differences in the amounts of lumber produced in the different regions of the antebellum United States by stating that differences existed in the amounts of timber possessed by each region, we would be wrong. This would not mean that there weren't differences in amounts produced; rather it would mean that these differences were caused by differing levels of regional demand for lumber and not by the amounts of timber available for harvest in each region.

The seventh and last group of industries is footloose, i.e., is not "pulled" towards either its resources or its markets. While the footloose industries are neither market- nor resource-oriented, they must be either consumer- 
or export-oriented since any industry which is not consumer-oriented must be export-oriented. In all probability, footloose industries would be export-oriented because transport costs are relatively unimportant to this type of industry. Since footloose industries would locate on the basis of non-transport cost factors, it would be extremely unlikely for firms in a footloose industry to end up as dispersed as consumer demand. It is only in the improbable latter case that a footloose industry could possibly be classified as being consumer-oriented.

We have seen that not all industries which are resource-oriented export their output. More specifically, those industries using ubiquitous resources will not export. The failure to recognize this fact has often led to an overemphasis on the importance of resource-oriented industries to regional development. For example, consider the research on the economic development of the antebellum South and Midwest. ${ }^{3}$ This research views antebellum regional economic development as being export led because virtually all the manufacturing in the South and Midwest was resourceoriented (and thus implicitly assumed to be export-oriented). This section has shown analytically that the former conclusion does not necessarily follow from the latter fact.

\section{EVIDENCE}

Empirical evidence on behalf of this argument may now be presented. Consider the data given in Table 1 . These data were compiled from the 1860 Census returns and give the coefficients of localization for thirteen of the fifteen largest Standard Industrial Classification (SIC) industries (by value added) as they existed in $1860 .{ }^{4}$ The coefficient of localization (COL) may be calculated by the following formula: ${ }^{5}$

$$
\mathrm{COL}_{\mathrm{i}}=\frac{1}{2} \sum_{\mathrm{j}=1}^{83}\left|\frac{\mathrm{VA}_{\mathrm{j}}^{\mathrm{i}}}{\mathrm{VA}_{\mathrm{T}}^{\mathrm{i}}}-\frac{\mathrm{P}_{\mathrm{j}}}{\mathrm{P}_{\mathrm{T}}}\right| \times 100 \%
$$

where

$$
\begin{aligned}
& \mathrm{VA}=\text { value added } \\
& \mathrm{P}=\text { population } \\
& \mathrm{i}=\text { industry designation } \\
& \mathrm{j}=\text { subregional designation } \\
& \mathrm{T}=\text { U.S. total }
\end{aligned}
$$

The COL's given in Table 1 were calculated over 83 subregions constructed out of the antebellum United States. As can be seen from the formula, the COL compares the distribution of the value added by the industry with the 
distribution of the antebellum population. The value of the COL can be interpreted as follows: (a) the closer the value of the COL is to zero, the more dispersed is the industry; (b) a value of the COL close to one hundred, on the other hand, means that the firms in an industry are concentrated in a few regions. ${ }^{6}$ In the former case, we would expect the firms in an industry to sell most of their output locally and thus would be consumer-oriented. In the latter case, we would expect the firms in an industry to export most of their output and thus would be export-oriented.

The industries listed in Table 1 are divided into four categories (Types). ${ }^{7}$ Type 1 consists of those resource-oriented industries which have the highest COL's; these industries were certainly export-oriented. Types 2 and 3 consist of those resource-oriented industries with COL's smaller than those in Type 1; more will be said about these groups in a moment. Type 4 consists of market-oriented industries, which by definition are consumeroriented.

The two Type 3 industries, the flour and meal industry and the lumber industry, have COL's lower than either of the market-oriented industries (Type 4) listed. ${ }^{8}$ More traditional evidence supports the quantitative evidence presented in Table 1 that the resources used by these industries and thus the industries themselves were very dispersed. As Victor Clark [2, p. $315]$ has said about the antebellum lumber industry: "Good timber was distributed as widely as the population and its manufacture was dispersed among numerous small sawmills ... catering to local consumers." Similarly, Clark [2, pp. 317-318] said that "the geography of flour milling [was] like that of lumbering" and that there was a "conjunction of abundant grain with expensive transportation...." Also, Niemi [9, p. 19] found that in 1860 "production was most localized in lumber and wood products" and "slightly less localized in food. . . ." This evidence leads us to classify these two industries into the sixth industry group outlined earlier in the paper, i.e., they used nearly ubiquitous resources and thus were both resource-oriented and consumer-oriented.

The industries designated as Type 2 in Table 1 have COL's which are larger than at least one of the market-oriented industries listed yet are smaller than those of the Type 1 industries. These industries may or may not have been consumer-oriented. The group exists because of uncertainty about where to draw the dividing line between consumer- and export-oriented industries.

The impact of the ideas presented in this paper on the distribution of Southern and Midwestern antebellum manufacturing by type can be clearly seen from Table 2 . Recognition that the flour and meal industry and the lumber industry, those designated as Type 3 in Table 1, were definitely consumer-oriented and not export-oriented reduces the importance of export-oriented industries substantially. This fact is shown in Column 2. Column 3 was calculated by assuming that the resourceoriented industries listed as Types 2 and 3 in Table 1, as well as some smaller industries not listed, were all consumer-oriented. Column 2 can be viewed as a lower bound for the percent of consumer-oriented antebellum manufacturing, whereas Column 3, if not an upper bound, is probably close to being one. 
TABLE 1

Industry Classification, By Type ${ }^{a}$ And Coefficient Of Localization

\begin{tabular}{ccccc}
\hline$(1)$ & $(2)$ & $(3)$ & $(4)$ & $(5)$ \\
SIC & SIC & Major 1860 & Rank by 1860 & COL \\
Number & Name & Industries & Value Added & \\
\hline
\end{tabular}

Type 1: Resource-Oriented and Not Consumer-Oriented

$\begin{array}{lllll}221 & \text { Weaving Mills, Cotton } & \text { Cotton Goods } & 1 & 54.18 \\ 314 & \text { Footwear } & \text { Boots \& Shoes } & 3 & 46.81 \\ 231 & \text { Men's \& Boy's Apparel } & \text { Clothing - Men's } & 5 & 48.44 \\ 331 & \text { Blast Furnace Products } & \begin{array}{l}\text { Iron, Bar, Sheet, \& } \\ \text { Railroad; Iron, pig }\end{array} & 6 & 46.93 \\ 223 & \text { Weaving Mills, Wool } & \text { Woollen Goods } & 8 & 52.04\end{array}$

Type 2: Resource-Oriented and Possibly Consumer-Oriented

311 Leather Tanning \& Finishing

$$
\text { Leather }
$$

251 Furniture Products

Furniture, cabinet, school \& other

342 Cutlery, Hand Tools \&

Agricultural ImplementsHardware

Hardware; (Misc.)

332 Iron Foundries

General Castings

Type 3: Resource-Oriented and Definitely Consumer-Oriented

242 Sawmills \& Planing Mills Lumber, Sawed 2

204 Grain Mill Products

Flour \& Meal

Type 4: Market-Oriented and Consumer-Oriented

371 Individuals' Vehicles

Carriages, Wagons \&

Carts

271 Printing \& Publishing

Printing \& Pubilishing

aSee the text and footnote 4 for discussion concerning the differences in the four types listed in the table.

Sources: Columns (1) and (2): U.S. [13]. Columns (3) - (5): Cohn [5].

\section{CONCLUSIONS}

The overall evidence is clear. While the large majority of Southern and Midwestern antebellum manufacturing was resource-oriented, only about one-half was export-oriented. This situation is due to the presence in the 
TABLE 2

1860 Manufacturing Value Added, South and Midwest, By Type

(1)

Industry Type
(2)

Percent of All

Manufacturing

Value Added:

Upper Bound
(3)

Percent of All

Manufacturing

Value Added:

Lower Bound

\section{Resource-Oriented}

Export-Oriented
$85 \%$ $70 \%$

$59 \%^{a}$
$42 \%^{\mathrm{b}}$


in Table 1 and expressed as a percent.

${ }^{\mathrm{b} C}$ Calculated as total manufacturing value added minus the value added of Types 2, 3, and 4 in Table 1 and expressed as a percent.

Source: Cohn [4].

antebellum United States of resource-oriented industries that used nearly ubiquitious resources. The major industries of this type were found (by use of coefficients of localization and narrative evidence) to be the flour and meal industry and the lumber industry. These industries were of sufficient size to substantially reduce the amount of antebellum manufacturing that was exported from producing regions.

\section{FOOTNOTES}

${ }^{1}$ The premier historical example of this connection is found in North [11].

'This point has been noted by various authors, for example Robertson [12, p. 251], but its significance has never been fully realized.

${ }^{3}$ See, for example, North [10] and Davis et. al. [6, pp. 548-561].

The two industries not listed in Table 1, engines and turbines (SIC\#351) and beverages (\#208), are special cases. The COL's for these industries are comparable with those for the Type 2 industries in Table 1 . However, very few of the firms in these industries were located in the South. The low value of the COL reflects the fact that the industry was very dispersed in the North and Midwest. Since consumer-oriented industries must, by definition, have firms located in all regions, the engines and turbines industry and the beverage industry cannot be consumer-oriented. In contrast, the firms in the industries listed in Table 1 as Type 2 were found in substantial amounts in all subregions of the antebellum U.S. (The Type 1 industries did not possess this feature.) Thus, all the Type 2 industries could possibly be consumeroriented. The Type 1 industries and the two industries not listed in Table 1 could not have been consumeroriented.
${ }^{5}$ The formula given provides answers identical to those obtained by the more standard approach of summing just the positive deviations (or just the negative deviations) from the base. See Isard [8, pp. 251-254] for further discussion of the COL.

${ }^{6}$ For a discussion of the construction of the subregions, see Cohn [5]. The entire Northeast was treated as one subregion. Since most antebellum manufacturing was located in the Northeast, the upper limit on the COL is about 63.00 (and not 100.00) for the analysis in this paper. Further since the Southern and Midwestern subregions used as a-basis for classification were smaller than states, the manufacturing that was consumeroriented sold primarily within these subregions. No major theoretical problems are apparent from having one large region and many small ones; e.g., the approach in this paper is similar to that used in Cebula [1].

The classification procedure is detailed in Cohn 4 and 5]. Briefly, the market-oriented industries (Type 4) were classified according to a modified list taken from Fuchs [7, pp. 152-153]. The division of resourceoriented industries into Type 1 and Type 2 is discussed in footnote 4.

${ }^{8}$ Indeed, of the 107 antebellum industries, these two industries had the lowest COL's. 


\section{REFERENCES}

1. Cebula, Richard J., "Our Economic Crisis in the United States," Economic Notes, No. 2-3, 1976.

2. Clark, Victor S. History of Manufactures in the United States. Vol. 1: 1607-1860. Washington, D.C.: Carnegie Institution of Washington, 1916; reprint ed., New York: Peter Smith, 1949.

3. Cohn, Edwin J., Jr. Industry in the Pacific Northwest and the Location Theory. Columbia University, N.Y.: King's Crown Press, 1954.

4. Cohn, Raymond L. "Local Manufacturing in the Antebellum South and Midwest." Business History Review, 54(Spring 1980):80-91.

5. Cohn, Raymond L. "A Locational Analysis of Manufacturing Activity in the Antebellum South and Midwest." (doctoral dissertation, University of Oregon, 1977).

6. Davis, Lance E.; Easterlin, Richard A.; and Parker, William N., eds. American Economic Growth. New York: Harper \& Row, 1972.
7. Fuchs, Victor R. Changes in the Location of Manufacturing in the United States Since 1929. New Haven, Conn.: Yale University Press, 1962.

8. Isard, Walter. Methods of Regional Analysis. Cambridge, Mass.: The M.I.T. Press, 1960.

9. Niemi, Albert W., Jr. State and Regional Patterns in American Manufacturing: 1860-1900. Westport, Conn.: Greenwood Press, 1974.

10. North, Douglass C. The Economic Growth of the United States, 1790-1860. Englewood Cliffs, N.J.: Prentice-Hall, 1965.

11. North Douglass C. "Location Theory and Regional Economic Growth." Journal of Political Economy 62 (June 1955): 243-258.

12. Robertson, Ross M. History of the American Economy. 3rd ed. New York: Harcourt Brace Jovanovich, Inc., 1973.

13. U.S. Office of Management and Budget. Standard Industrial Classification Manual, 1972. 